\title{
Effects of short and extended fasting periods and cattle breed on glycogenolysis, sarcomere shortening and Warner-Bratzler shear force
}

\author{
H. A. O'Neill" ${ }^{1 \#}$, E. C. Webb ${ }^{2}$, L. Frylinck ${ }^{3}$ \& P. E. Strydom ${ }^{3}$ \\ ${ }^{1}$ Department of Animal, Wildlife and Grassland Sciences, University of the Free State, Bloemfontein, South Africa 9300 \\ ${ }^{2}$ Department of Animal and Wildlife Sciences, University of Pretoria, Pretoria, South Africa 0002 \\ ${ }^{3}$ Animal Production Institute, Agricultural Research Council of South Africa, Private Bag X2, Irene, South Africa 0062
}

(Received 17 March 2017; Accepted 26 October 2017; First published online 13 November 2017)
Copyright resides with the authors in terms of the Creative Commons Attribution 4.0 South African Licence.
See: http://creativecommons.org/licenses/by/4.0/za
Condition of use: The user may copy, distribute, transmit and adapt the work, but must recognise the authors and the South African Journal of Animal Science.

\begin{abstract}
The effects of short (three hours) and extended (24 hours) feed withdrawal periods and three cattle breeds on muscle energy metabolism, sarcomere length, and meat quality were investigated. Brahman (Br), Nguni $(\mathrm{Ng})$, and Simmental $(\mathrm{Sm})$ bulls were subjected to ante-mortem feed withdrawal of three hours $(\mathrm{Br} 3, \mathrm{n}$ $=10 ; \mathrm{Ng} 3, \mathrm{n}=10$; and Sm3, $\mathrm{n}=10$ ) or 24 hours (Br24, $\mathrm{n}=10 ; \mathrm{Ng} 24, \mathrm{n}=10$; and Sm24, $\mathrm{n}=10)$. longissimus was used as the reference muscle for sampling. $\mathrm{pH}$, and temperature was recorded at 1, 2, 3, 6, 9 , and 24 hours post mortem. Samples for energy metabolites were removed at 3, 6, 9 and 24 hours post mortem. Glycogen, glucose-6-phosphate and creatine phosphate concentration were determined at each time interval as glycosyl units after hydrolysis. Samples to determine sarcomere length were removed at one and three days post mortem. Homogenates of the samples were placed under a 31,000 magnification microscope and sarcomere lengths were measured. Warner-Bratzler shear force (WBSF) was measured with an Instron meter at 1, 7 and 14 days post mortem. Glycogen was lower for Br24 and Ng24. There were no differences in glucose-6-phosphate, rate of creatine phosphate decline, average sarcomere length, or WBSF for Br24 and Ng24 compared with $\mathrm{Br} 3$ and $\mathrm{Ng} 3$. There were no differences for WBSF between $\mathrm{Br} 3$, $\mathrm{Ng} 3$ and Sm3. Glycogen concentration was higher for Sm24 compared with Sm3; glucose-6-phosphate was lower for Sm24 compared with Sm3; and the rate of creatine phosphate decline was higher for Sm24 compared with Sm3. Average sarcomere length was shorter and WBSF was higher for Sm24 compared with Sm3. The effect of prolonged ante-mortem feed withdrawal on tenderness is breed specific. Warner-Bratzler shear force was affected significantly by an extended feed withdrawal period in Simmental cattle only.
\end{abstract}

Keywords: Acidification, creatine phosphate depletion, fasting, hypometabolism, meat tenderness

\# Corresponding author: oneillha@ufs.ac.za

\section{Introduction}

In the 1990s, researchers stated that available muscle glycogen at the time of slaughter had a direct effect on post-mortem lactate production and that low lactate concentrations caused high ultimate $\mathrm{pH}$ values and tough meat (Tornberg, 1996). However, recent research has indicated that adenosine triphosphate (ATP) hydrolysis in the anoxic cell leads to the production of protons, which causes lower $\mathrm{pH}$ values (Scheffler et al., 2011). In the anoxic cell, ATP is replenished by the breakdown of creatine phosphate and degradation of carbohydrates via anaerobic biochemical pathways (Bendall, 1973). The energy needed for post-mortem ATP maintenance is supplied by the stepwise degradation of glycogen through glycogenolysis and glycolysis. Glycogenolysis is the first step of glycogen degradation. The enzyme glycogen phosphorylase is involved in glycogenolysis and releases glucose rapidly as glucose-1-phosphate (G-1-P) (Newsholme \& Start, 1979). Compared with glycogenolysis, which is the breakdown of glycogen to G-1-P and glucose, glycolysis is the degradation of G-1-P and glucose. G-1-P is converted to glucose-6-phospate by the enzyme phosphoglucomutase (Campbell, 1995) in which ATP is hydrolysed and protons are released (Scheffler et al., 2011). Further ATP hydrolysis occurs when glucose-6-phophate is ultimately metabolized to fructose-1,6-biphosphate. The ATP is then replenished by ADP, creatine phosphate, and glycogen. Therefore, muscle glycogen and creatine phosphate concentration at the time of slaughter determine the degree of homeostatic ATP balance (Savell, 2005). The last few steps of glycolysis, including the conversion 
of pyruvate to lactate, involve the incorporation of protons in biochemical pathways. Protons are 'consumed' and $\mathrm{pH}$ declines at a slower rate. Lactate dehydrogenase catalyses the reduction of pyruvate to lactate in the fibre cytosol (Newsholme \& Leech, 1983). Although lactate synthesis retards acidification, it is still a good indirect marker of fibre metabolic conditions that induce increased $\mathrm{H}^{+}$release which determines the extent of pH decline (Scheffler et al., 2011).

Rigor mortis and ATP hydrolysis occur in two phases. In phase 1, ATP hydrolysis causes a decline and eventual 'disappearance' of ATP early post mortem, which is associated with an accumulation of $\mathrm{H}^{+}$and $\mathrm{Pi}$ and followed by $\mathrm{pH}$ decline (Vetharaniam et al., 2010). In phase 2, sustained anoxia results in depletion of ATP, leading to muscle stiffness as cross-bridges form between actin and myosin during the development of rigor mortis (Jeacocke, 1984).

The availability of muscle glycogen at slaughter is influenced by a number of extrinsic and intrinsic factors. Extrinsic factors include availability of food and water, exposure to stressful conditions, and level of activity. In live animals, glucose is the primary source of energy. Gluconeogenesis in live animals is triggered by fasting, stressful conditions and muscle contraction. Glucagon is involved not only in gluconeogenesis of fasting animals (Mark, 2005), but also in catecholamines of fasting and stressed animals. An animal's drive to maintain glucose homeostasis activates the hypothalamic-pituitary-adrenal axis, which results in elevated circulating catecholamines. Stressors that activate the hypothalamic-pituitary-adrenal axis include mixing animals from different groups, transport, and feed and water withdrawal. Activation of the hypothalamicpituitary-adrenal axis evokes a number of biochemical changes such as energy depletion through increased glycogenolysis (Schaefer et al., 2001). Contracting muscles need glucose and ATP as energy sources. In live animals, glycogenolysis provides skeletal muscles with the energy sources for muscle contraction. Animals that are transported may experience increased muscular activity (Ferguson \& Warner, 2008).

Intrinsic muscle properties differ among species, breeds, and anatomical location, and are dependent mainly on muscle fibre types. These differ in terms of glycogen concentration (Hopkins, 2006) and therefore not all muscle fibres are affected to the same degree by cold shortening (Hannula \& Puolanne, 2004). Results from O'Neill (2016) indicated that the m. longissimus of Nguni cattle contained more Type I or oxidative muscle fibres than Simmental-type cattle.

Fasting is often applied in the beef production industry for practical reasons. Feed withdrawal is applied to meat-producing animals during the ante-mortem period to minimize microbial contamination of carcasses (Abouzeed et al., 2000). To survive excessive heat conditions, European cattle breeds need to be able to regulate body temperature. Heat production in some Bos taurus breeds can be lowered through restricted feed intake. A reduction in metabolizable energy intake lowers the metabolic rate and consequently the heat production of some cattle breeds (Purwanto et al., 1990). In some instances, feedlot cattle producers limit feed intake during early summer. This management practice is used as a successful tool to enhance animal comfort in hot climates (Mader et al., 2002).

The effects of feed withdrawal periods on glycogen metabolism for different cattle breeds have not been quantified. Therefore, the effects of short and extended feed withdrawal periods, as applied practically to animals destined for slaughter, on energy metabolism and Warner-Bratzler shear force (WBSF) was investigated for cattle breed types Bos indicus, Bos Taurus and Sanga. Brahman-type cattle represented Bos indicus in this study. This breed is known for its longevity, mothering ability and efficient beef production (Hammond et al., 1998). Nguni-type cattle represented Sanga in this study. This breed developed through a long process of natural selection in a climatically challenging environment. It is a small- to medium-framed early maturing breed known for its fertility and resistance to ticks and diseases (Bester et al., 2005) and is therefore one of the favourite breeds among milk and meat producers of South Africa (Frisch, 1973). Although it is a smaller and multipurpose breed, the Nguni competes well with established breeds in productive performance and meat quality. In the study by Jama et al. (2008), Nguni meat quality was shown to be as good as that from Angus and Bonsmara under adverse conditions. Simmental-type cattle represented Bos taurus in this study. This breed is known for its high growth rate, docile disposition and good carcass quality (Voisinet et al., 1997).

\section{Materials and Methods}

Sixty bulls were selected on phenotype from various commercial farmers. The animals used in this study represented crossbreeds that are often used in meat production in South Africa ${ }^{1}-\operatorname{Brahman}(n=20)$, Nguni $(n=20)$, and Simmental $(n=20)$ bulls were purchased at age 10-12 months, and average weight of $158 \pm 2.5 \mathrm{~kg}$ ). Animals were transported to the Agricultural Research Council - Animal Production Institute (ARC-API), Irene, where they were placed under feedlot conditions for 100 to 120 days until slaughter. The

\footnotetext{
${ }^{1}$ According to Dave Ford of the Feedlot Association of South Africa and committee member of the Red Meat Research and Development Trust (RMRDT)
} 
animals received implants (Revalor-S) as applied in South African feedlot practices to improve feedlot performance. The animals were housed in small pens holding ten animals each, each animal having $10 \mathrm{~cm}^{2}$ and $50 \mathrm{~cm}$ of feed-bunk space. Clean fresh water was available at all times. A standard type of high concentrate diet was supplied (12 MJ/kg DM, 13,5\% protein) to which they were allowed to adapt for a threeweek period from high levels of hay $(15 \%)$ to low levels $(6 \%)$. Animals in each breed were blocked for weight and allocated to their pens. Within each breed group, animals were weighed at two-weekly intervals, and daily health observations were made on morbidity, consistent breathing and manure consistency. All these actions were necessary to comply with rules of the Ethics Committee of the ARC (APIEC 11/025).

Each breed was subjected to a short (three hours) feed withdrawal period $\left(\mathrm{Br}_{3}, \mathrm{n}=10 ; \mathrm{Ng}_{3}, \mathrm{n}=10\right.$, and $\mathrm{Sm}_{3}, \mathrm{n}=10$ ) or an extended (24 hours) feed withdrawal period $\left(\mathrm{Br}_{24}, \mathrm{n}=10 ; \mathrm{Ng}_{24}, \mathrm{n}=10\right.$, and $\mathrm{Sm}_{24}, \mathrm{n}=$ 10). The experimental design was a $3 \times 2$ factorial design of six groups with ten animals each. Animals from the three-hour feed withdrawal group were weighed the day before slaughter. Feed withdrawal commenced before transport $(6: 00 \mathrm{am})$. Animals were loaded onto a truck and transported over $50 \mathrm{~km}$ (about 1 hour). At the abattoir they were offloaded, rested for two hours, and slaughtered (start 11:00). Animals from the 24hour feed withdrawal group were weighed and loaded onto a truck. They were transported over $50 \mathrm{~km}$ (about $1 \mathrm{~h}$ ) and offloaded at the abattoir, where they were left to stand overnight until slaughter the next day (start 8:30).

Animals were slaughtered at A age (0 incisors) with a fatness class of 2 or 3 (lean-medium fatness) according to the current South African beef classification system (Government Gazette No. 5092, 1993). After exsanguination, carcasses were dressed, halved, and chilled at $4{ }^{\circ} \mathrm{C}$ within two hours of slaughter. Samples were removed from the reference muscle $m$. longissimus on the left and right side of each carcass as indicated in Figure 1.

\begin{tabular}{l|l|l|}
\multicolumn{2}{c}{ Left } \\
L1 & \multicolumn{1}{c}{ Cranial } \\
L2 & WBSF at 1 day post mortem & WBSF 7 days post mortem \\
L3 & & \\
L4 & Sarcomere length and energy metabolites & WBSF 14 days post mortem \\
\cline { 2 - 2 } L5 & &
\end{tabular}

WBSF: Warner-Bratzler shear force

Caudal

Figure 1 Schematic representation of $m$. longissimus at L1-L6 indicating approximate anatomical regions for sampling for various analyses

$\mathrm{pH}$ and temperature decline were measured at 1, 2, 3, 6, 9, and $24(\mathrm{pHu})$ hours after slaughter with a digital handheld meat $\mathrm{pH}$ meter (Unitemp) fitted with a polypropylene spear type gel electrode.

To determine energy metabolites, $20 \mathrm{~g}$ muscle was removed from m. longissimus 1, 3, 6 and 24 hours post mortem. Samples were covered with aluminium foil, frozen with liquid nitrogen, and then ultra-frozen at $0{ }^{\circ} \mathrm{C}$ until analyses. Samples from the four time intervals were used for biochemical analyses (post-mortem energy metabolites) using perchloric acid as described by Dalrymple \& Hamm (1973). Glycogen concentration was determined as glycosyl units after hydrolysis with $\alpha$-amyloglucosidase and correction for glucose concentration in the extract to the method of Keppler \& Decker (1974). Glucose-6-phosphate and creatine phosphate were determined in perchloric acid extracts according to Lamprecht \& Stein (1965).

To determine sarcomere length $(\mu \mathrm{m})$, samples were removed from $m$. longissimus at 1 and 3 days post mortem and prepared according to Hegarty \& Naudé (1970). These samples were homogenized in approximately $15 \mathrm{~m} \ell$ distilled water using an ultra Turrax blender at low speed. A few droplets of homogenate were mounted on a slide, covered with a cover slip, and immediately viewed under an Olympus B340 system microscope at 31,000 magnification, equipped with a CC12 video camera (Olympus, Tokyo, Japan) and attached to a video image analyser. Fifty sarcomere lengths were recorded per sample.

Three 20-25 cm thick whole-loin cuts were removed from $\mathrm{m}$. longissimus on the right and left side for WBSF evaluations. Each of the three cuts was vacuum packed, and aged for 1,7 , and 14 days post mortem at $4{ }^{\circ} \mathrm{C}$, frozen, and stored $\left(-25^{\circ} \mathrm{C}\right)$ for later determination of WBSF. Blocks of approximately $6 \times 6 \times 2.5 \mathrm{~cm}$ were cut from $\mathrm{m}$. longissimus at 24 hours, 7 days and 14 days post mortem. Frozen samples $\left(-20^{\circ} \mathrm{C}\right)$ were processed into $30 \mathrm{~mm}$ steaks with a bandsaw. The frozen steaks were thawed at $4{ }^{\circ} \mathrm{C}$ for 24 hours, after 
which they were cooked using an oven-broiling method with direct radiant heat (Mielé, model H217, Mielé \& Cie, Gütersloh, Germany; American Meat Science Association (AMSA), 1995). The steaks were broiled at $260{ }^{\circ} \mathrm{C}$ (pre-set) to $70^{\circ} \mathrm{C}$ internal temperature and cooled down to room temperature $\left(18{ }^{\circ} \mathrm{C}\right)$. Eight round cores (12.7 mm diameter) were removed from the steaks parallel to the long axis of the fibres (AMSA, 1995). Each core was sheared once through the centre, perpendicular to the fibre direction, with a Warner-Bratzler shear device mounted on a Universal Instron apparatus (Model 4301, Instron Ltd, Buckinghamshire, UK; crosshead speed $200 \mathrm{~mm} / \mathrm{min})$. WBSF was measured as the peak force $(\mathrm{kg})$ average for eight cores per sample.

For those observations that were recorded at different time intervals $\mathrm{pH}$, temperature, WBSF, length, glycogen, glucose-6-phosphate and creatine phosphate), an analysis of variance for contrast variables was done by the GLM procedure of SAS (2008) at a significance level of $P<0.05$. Interactions between breed type and feed withdrawal were taken into account.

\section{Results and discussion}

$\mathrm{pH}$ did not differ between breeds at any of the post-mortem time intervals when feed was withdrawn for 24 hours before slaughter. $\mathrm{pH}$ for $\mathrm{Ng}_{24}$ was lower at two hours post mortem compared with $\mathrm{Br}_{24}$ and $\mathrm{Sm}_{24}$, but this observation was not statistically significant (Table 1). When feed was withdrawn for three hours before slaughter, $\mathrm{pH}$ for $\mathrm{Br}_{3}$ was lower $(P<0.05)$ compared with $\mathrm{Ng}_{3}$ and $\mathrm{Sm}_{3}$ at two hours post mortem. There were no other differences between breeds when feed was withdrawn for three hours.

Table 1 Effect of breed type and feed withdrawal period on post-mortem $\mathrm{pH}$ decline, ultimate $\mathrm{pH}$ and temperature in $m$. longissimus of Brahman-, Nguni- and Simmental-type cattle

\begin{tabular}{|c|c|c|c|c|c|}
\hline \multirow{2}{*}{ pH } & \multirow{2}{*}{ Feed withdrawal } & \multicolumn{3}{|c|}{ Breed type } & \multirow{2}{*}{ SEM } \\
\hline & & Brahman & Nguni & Simmental & \\
\hline \multirow{2}{*}{ At 1 hour } & 3 hours & 6.5 & 6.6 & 6.6 & 0.06 \\
\hline & 24 hours & 6.6 & 6.6 & 6.7 & 0.06 \\
\hline \multirow{2}{*}{ At 2 hours } & 3 hours & $6.2^{\mathrm{a}^{*}}$ & $6.4^{\mathrm{b}}$ & $6.4^{\mathrm{b}}$ & 0.07 \\
\hline & 24 hours & $6.5^{* *}$ & 5.4 & 6.5 & 0.06 \\
\hline \multirow{2}{*}{ At 3 hours } & 3 hours & $6.1^{*}$ & 6.2 & 6.3 & 0.07 \\
\hline & 24 hours & $6.3^{* *}$ & 6.3 & 6.4 & 0.07 \\
\hline \multirow{2}{*}{ At 6 hours } & 3 hours & $5.9^{*}$ & $5.9^{*}$ & 6.0 & 0.05 \\
\hline & 24 hours & $6.0^{* *}$ & $6.2^{* *}$ & 6.1 & 0.05 \\
\hline \multirow{2}{*}{ At 9 hours } & 3 hours & $5.7^{*}$ & $5.8^{*}$ & 5.9 & 0.06 \\
\hline & 24 hours & $5.9^{* *}$ & $5.9^{* *}$ & 5.9 & 0.05 \\
\hline \multirow{2}{*}{ At 24 hours } & 3 hours & 5.8 & $5.6^{*}$ & 5.8 & 0.06 \\
\hline & 24 hours & 5.8 & $5.7^{* *}$ & 5.8 & 0.06 \\
\hline \multicolumn{6}{|l|}{ Temperature } \\
\hline \multirow{2}{*}{ At 1 hour } & 3 hours & 38.7 & $34.9^{*}$ & 38.8 & 0.42 \\
\hline & 24 hours & 37.9 & $38.9^{* *}$ & 38.6 & 0.36 \\
\hline \multirow{2}{*}{ At 3 hours } & 3 hours & $27.8^{\mathrm{ab}}$ & $26.6^{a}$ & $28.7^{b}$ & 1.04 \\
\hline & 24 hours & $28.9^{\mathrm{a}}$ & $25.2^{\mathrm{b}}$ & $29.0^{\mathrm{a}}$ & 0.86 \\
\hline \multirow{2}{*}{ At 6 hours } & 3 hours & $17.3^{*}$ & 15.6 & $17.1^{*}$ & 1.29 \\
\hline & 24 hours & $19.4^{\mathrm{a}^{* t}}$ & $16.3^{\mathrm{b}}$ & $19.5^{\mathrm{a}^{* *}}$ & 1.33 \\
\hline \multirow{3}{*}{ At 9 hours } & 3 hours & $13.8^{*}$ & 12.5 & 14.2 & 0.76 \\
\hline & 24 hours & $16.8^{\mathrm{a}^{* *}}$ & $13.4^{\mathrm{b}}$ & $15.5^{\mathrm{a}}$ & 0.66 \\
\hline & 3 hours & 4.2 & 3.8 & 4.1 & 1.05 \\
\hline At 24 hours & 24 hours & 3.8 & 3.6 & 3.7 & 0.85 \\
\hline
\end{tabular}

${ }_{*, * *}^{\mathrm{a}, \mathrm{b}}$ Means with different superscripts within the same row differ significantly $(P<0.05)$

${ }^{*},{ }^{* *}$ Means with different superscripts within the same column differ significantly $(P<0.05)$ 
Within breeds, $\mathrm{pH}$ differed between withdrawal periods. $\mathrm{For}_{24}$, $\mathrm{pH}$ was higher $(P<0.05)$ at 2, 3 and 9 hours post mortem compared with $\mathrm{Br}_{3}$. At 24 hours post mortem, $\mathrm{pH}$ did not differ between $\mathrm{Br}_{24}$ and $\mathrm{Br}_{3}$. Similarly, $\mathrm{pH}$ at 6 and 24 hours post mortem was higher $(P<0.05)$ for $\mathrm{Ng}_{24}$ than for $\mathrm{Ng}_{3}$. There were no differences in $\mathrm{pH}$ between $\mathrm{Sm}_{24}$ and $\mathrm{Sm}_{3}$ at any of the post-mortem time intervals.

Carcass temperature between breeds and within feed withdrawal periods differed significantly as a result of different carcass weights between breeds. Carcass temperature was lower $(P<0.05)$ for $\mathrm{Ng}_{24}$ than for $\mathrm{Br}_{24}$ and $\mathrm{Sm}_{24}$ at 3, 6 and 9 hours post mortem. Carcass temperature was lower $(P<0.05)$ for $\mathrm{Ng}_{3}$ than for $\mathrm{Sm}_{3}$ at 3 hours post mortem. Lower observed carcass temperatures were as expected because Nguni has been classified as an indigenous small-frame breed by Lepen (1996), Bester et al. (2005), Strydom et al. (2008), and Jama et al. (2008). Carcass temperature differed significantly in some instances between feed withdrawal treatments and within breed types and could be as a result of post-mortem caloricity. 'Postmortem caloricity' is a term that is applied in forensic science to a condition in which there is a rise in muscle temperature because of post-mortem glycogenolysis (Bardale, 2011). Carcass temperature was higher $(P$ $<0.05)$ for $\mathrm{Br}_{24}$ compared with $\mathrm{Br}_{3}$ at 6 and 9 hours post mortem. Carcass temperature was higher $(P<0.05)$ for $\mathrm{Ng}_{24}$ than for $\mathrm{Ng}_{3}$ at 1 hour post mortem. Carcass temperature was higher $(P<0.05)$ for $\mathrm{Sm}_{24}$ than for $\mathrm{Sm}_{3}$ at 6 hours post mortem. There was no difference in temperature decline between $\mathrm{Ng}_{24}$ and $\mathrm{Ng}_{3}$. Glycogen was depleted to less than $30 \mu \mathrm{mol}$ glycosyl units $/ \mathrm{g}$ at slaughter for $\mathrm{Ng}_{24}$ and post-mortem caloricity was possibly less.

Figure 2 shows the temperature and $\mathrm{pH}$ relationship of all treatment groups on a graph. None of the treatment groups fell within the high rigor temperature or cold shortening window as defined by Pearson \& Young (1989). None of the groups was susceptible to sarcomere shortening by definition. The term 'high rigor temperature carcasses' refers to beef carcasses that undergo rapid $\mathrm{pH}$ fall while muscle temperature is still high.

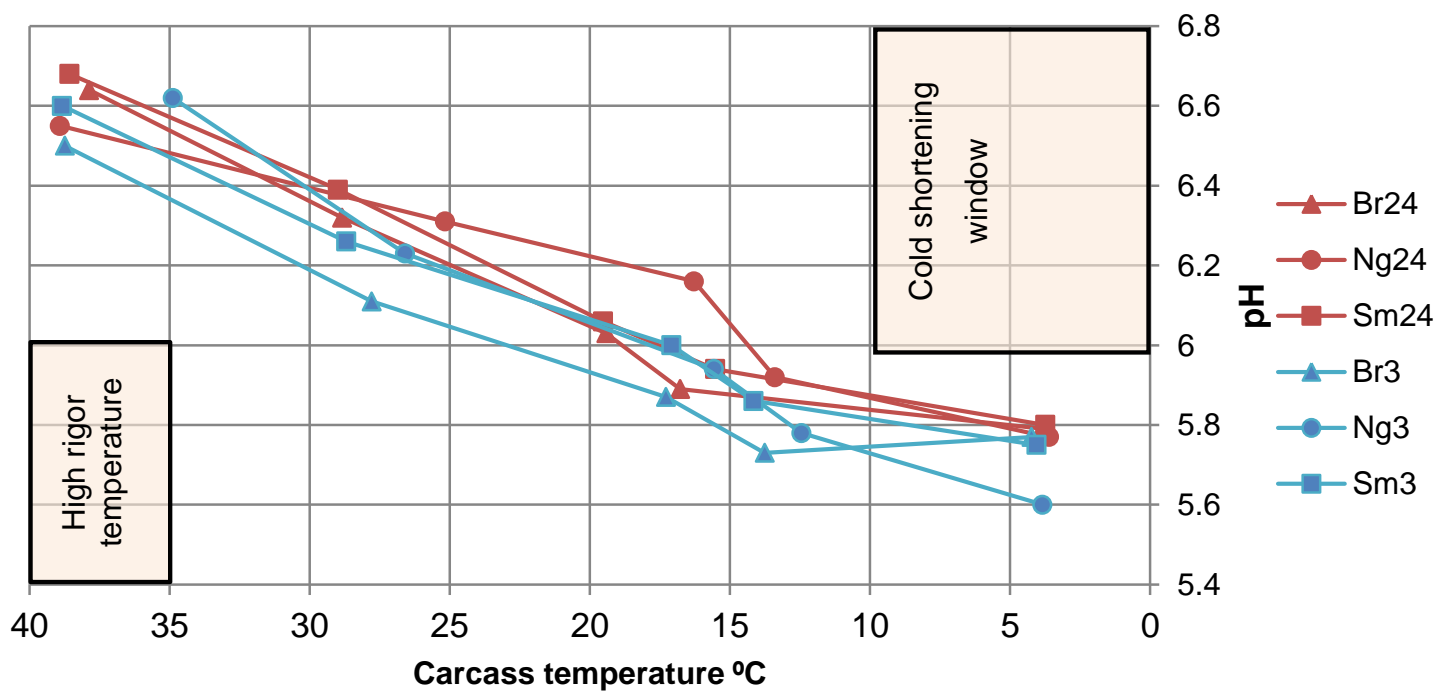

Figure 2 Temperature and pH relationship of $m$. longissimus of Brahman-, Nguni- and Simmental-type cattle subjected to three or 24 hours' feed withdrawal

Feed withdrawal period had significant effects on muscle glycogen and glucose-6-phosphate concentration in each breed type (Tables 2 and 3). Ferguson \& Warner (2008) stated that an animal's need for energy is a basic one and animals that are transported may experience hunger. The inability of an animal to resolve this state may invoke further psychological distress (Ferguson \& Warner, 2008). Hunger triggers a range of metabolic processes such as glycogenolysis, glycolysis and lipolysis to make glucose available as an energy source (Ferguson \& Warner, 2008). Extended feed withdrawal ante mortem had significant effects on muscle glycogen concentration for Brahman and Nguni at 1 hour post mortem. For $\mathrm{Br}_{24}$ and $\mathrm{Ng}_{24}$, glycogen at slaughter (1 hour post mortem) was lower compared with $\mathrm{Br}_{3}$ and $\mathrm{Ng}_{3}$. In terms of pH values from Table 1, $\mathrm{pH}$ for $\mathrm{Br}_{24}$, and $\mathrm{Ng}_{24}$ remained higher at 3, 6 and 9 hours post mortem compared with $\mathrm{Br}_{3}$ and $\mathrm{Ng}_{3}$. The extent of post-mortem muscle acidification is dependent on the amount of available muscle glycogen (Pösö \& Puolanne, 2005) and explains the higher pH values that were measured in $\mathrm{m}$. longissimus of $\mathrm{Br}$ and $\mathrm{Ng}$, which were subjected to an extended feed withdrawal period. 
Table 2 Effect of breed type and feed withdrawal period on glycogen of $m$. longissirnus at 1, 3, 6 and 24 hours post mortem

\begin{tabular}{|c|c|c|c|c|}
\hline \multirow{2}{*}{$\begin{array}{l}\text { Glycogen } \\
(\mu \mathrm{mol} \text { glycosyl units } / \mathrm{g})\end{array}$} & \multirow{2}{*}{ Feed withdrawal } & \multicolumn{3}{|c|}{ Breed type } \\
\hline & & Brahman & Nguni & Simmental \\
\hline \multirow{2}{*}{ at 1 hour } & 3 hours & $59.3^{\mathrm{a}^{\star}} \pm 4.77$ & $34.67^{b^{*}} \pm 5.62$ & $46.45^{b} \pm 4.68$ \\
\hline & 24 hours & $48.68^{a^{\star \star *}} \pm 5.02$ & $19.08^{b^{\star \star}} \pm 5.57$ & $53.41^{a} \pm 4.69$ \\
\hline \multirow{2}{*}{ at 3 hours } & 3 hours & $45.44^{a} \pm 4.66$ & $28.79^{b} \pm 5.49$ & $40.81^{\mathrm{ab}} \pm 4.57$ \\
\hline & 24 hours & $43.17^{\mathrm{a}} \pm 4.91$ & $19.23^{b} \pm 5.44$ & $39.40^{a} \pm 4.58$ \\
\hline \multirow{2}{*}{ at 6 hours } & 3 hours & $42.81^{\mathrm{a}} \pm 4.69$ & $25.55^{b} \pm 5.52^{b}$ & $34.95^{\mathrm{ab}} \pm 4.6$ \\
\hline & 24 hours & $39.00^{\mathrm{a}} \pm 4.93$ & $17.63 \pm 5.46$ & $32.16^{a} \pm 4.6$ \\
\hline \multirow{2}{*}{ at 24 hours } & 3 hours & $24.05^{\mathrm{a}} \pm 4.61$ & $1.73^{b} \pm 5.42$ & $13.88^{a} \pm 4.51$ \\
\hline & 24 hours & $18.83^{\mathrm{a}} \pm 4.84$ & $2.38^{b} \pm 5.36$ & $17.91^{\mathrm{a}} \pm 4.52$ \\
\hline
\end{tabular}

Table 3 Effect of breed type and feed withdrawal period on glucose-6-phosphate of $m$. longissimus at 1, 3 , 6 , and 24 hours post mortem

\begin{tabular}{|c|c|c|c|c|c|}
\hline \multirow{2}{*}{$\begin{array}{l}\text { Glucose-6-phosphate } \\
\text { ( } \mu \mathrm{mol} \text { glycosyl units } / \mathrm{g})\end{array}$} & \multirow{2}{*}{ Feed withdrawal } & \multicolumn{3}{|c|}{ Breed type } & \multirow{2}{*}{ SEM } \\
\hline & & Brahman & Nguni & Simmental & \\
\hline \multirow{2}{*}{ at 1 hour } & 3 hours & $2.2^{\mathrm{a}}$ & $2.7^{\mathrm{a}}$ & $4.3^{\mathrm{b}_{*}}$ & \multirow{2}{*}{0.51} \\
\hline & 24 hours & 3.1 & 2.4 & $2.6^{\star *}$ & \\
\hline \multirow{2}{*}{ at 3 hours } & 3 hours & 2.2 & 2.6 & 3.1 & \multirow{2}{*}{0.56} \\
\hline & 24 hours & 2.3 & 1.6 & 2.3 & \\
\hline \multirow{2}{*}{ at 6 hours } & 3 hours & 2.1 & 2.6 & 3.4 & \multirow{2}{*}{0.72} \\
\hline & 24 hours & 2.0 & 1.6 & 2.4 & \\
\hline \multirow{2}{*}{ at 24 hours } & 3 hours & 9.6 & 7.9 & 8.0 & \multirow{2}{*}{0.95} \\
\hline & 24 hours & $9.3^{\mathrm{a}}$ & $6.2^{\mathrm{b}}$ & $8.5^{\mathrm{b}}$ & \\
\hline
\end{tabular}

Interestingly, the effect of an extended feed withdrawal period on muscle glycogen concentration was not as expected for $\mathrm{Sm}$. At one hour post mortem, higher glycogen concentrations were measured for $\mathrm{Sm}_{24}$ compared with $\mathrm{Sm}_{3} . \mathrm{Sm}_{24}$ showed higher $(P>0.05)$ glycogen at 1,6 and 24 hours, and did not differ at 3 hours post mortem compared with $\mathrm{Sm}_{3}$. At 1 hour post mortem glucose-6-hosphate was lower $(P<0.05)$ for $\mathrm{Sm}_{24}$ compared with $\mathrm{Sm}_{3}$. The rate of glycogenolysis was slower for $\mathrm{Sm}_{24}$ compared with $\mathrm{Sm}_{3}$ just before slaughter until 1 hour post mortem. Although hunger classically triggers glycogenolysis in ruminants (Ferguson \& Warner 2008), it may lower the metabolic rate in other mammalian species to preserve energy (Bronnikov et al., 1990). Some mammalian species have the ability to suppress the metabolic rate to conserve energy, water, or oxygen to survive extended periods of food restriction. This metabolic suppression is often accompanied by a decrease in core body temperature, that is, hibernation or daily torpor (Staples, 2016). Fujita et al. (2013) identified a bovine hibernation-specific protein complex in Holstein non-pregnant cows that increased as soon as fasting commenced. This means that cattle may also lower (Bos taurus) their metabolic rate as soon as feed is withdrawn. This could have been the result of an energysparing effect for Simmental during fasting as explained by Malatesta et al. (2007).

Although animals were purchased from commercial farmers and could represent breeds only phenotypically, breed type had significant effects on glycogen and glucose-6-phosphate concentration at slaughter. These observations could be due to possible differences in muscle fibre types between breeds 
because oxidative muscle fibre types contain less glycogen (Judge et al., 1989; In: Immonen \& Puolanne, 2000). Glycogen concentration for $\mathrm{Ng}$ was lower at all post mortem times compared with $\mathrm{Br}$ and $\mathrm{Sm}$. In combination with lower glycogen, $\mathrm{Ng}$ showed significant, but not meaningful higher $\mathrm{pH}$ values compared with Brahman at nine hours post mortem compared with $\mathrm{Br}$ and $\mathrm{Sm}$ at 24 hours post mortem. $\mathrm{pH}$ of muscle that contains less glycogen declines at a slower rate or remains high (above pH 6.0) (Bate-Smith, 1949; Lawrie, 1953; Howard \& Lawrie, 1956; Tarrant et al., 1972; Hamm, 1974). Glucose-6-phosphate was significantly lower for $\mathrm{Ng}_{24}$ than for $\mathrm{Br}_{24}$ and $\mathrm{Sm}_{24}$ at 24 hours post mortem as initially there was less glycogen (less than $30 \mu \mathrm{g} / \mathrm{mmol}$ glycogen) owing to genetic muscle fibre type differences.

For Brahman and Nguni bulls, there were no differences in sarcomere lengths (Table 4), rate of creatine phosphate decline (Figure 3) and WBSF (Table 5) between the 24-hour and 3-hour treatments. However, Simmental bulls subjected to the extended treatment showed an increased rate of creatine phosphate decline, average sarcomere length was shorter $(P<0.05)$ at 1 and 3 days post mortem, and WBSF at 1,7 and 14 days post mortem was higher $(P<0.05)$, in comparison with Simmental bulls subjected to the short treatment. Various conditions for sarcomere shortening have been summarized by Savell et al. (2005). These include cold shortening, thaw and heat rigor. As none of the breeds subjected to the treatments fell within the heat rigor or cold shortening window (Figure 2) as defined by Pearson \& Young (1989), cold shortening and thaw and heat rigor were eliminated as risk factors from this study. From the results in this study, it seems that another condition for sarcomere shortening should be defined as depletion of creatine phosphate before six hours post mortem when the carcass is still warm. Enzymes that control ATP metabolism and glycolysis of living muscle are still active post mortem, but can maintain ante-mortem levels of ATP only for as long as creatine phosphate is available (Bendall, 1951; Lawrie, 1953; Tarrant et al., 1972; Bendall, 1973; Bertram et al., 2002). Because the rate of creatine phosphate depletion was higher for $\mathrm{Sm}_{24}$ compared with $\mathrm{Sm}_{3}$, sarcomere shortening occurred and rigor set in before six hours post mortem.

Table 4 Effect of breed type and feed withdrawal period on average sarcomere length of $m$. longissimus at 1 day and 3 days post mortem

\begin{tabular}{|c|c|c|c|c|c|}
\hline \multirow{2}{*}{ Average sarcomere length $(\mu \mathrm{m})$} & \multirow{2}{*}{ Feed withdrawal } & \multicolumn{3}{|c|}{ Breed } & \multirow{2}{*}{ SEM } \\
\hline & & Brahman & Nguni & Simmental & \\
\hline \multirow[b]{2}{*}{1 day } & 3 hours & $1.7^{\mathrm{a}}$ & $1.6^{\mathrm{b}}$ & $1.7^{\mathrm{a}^{* *}}$ & \multirow{2}{*}{0.04} \\
\hline & 24 hours & $1.7^{\mathrm{a}}$ & $1.6^{\mathrm{b}}$ & $1.6^{\mathrm{b}^{*}}$ & \\
\hline \multirow{2}{*}{3 days } & 3 hours & $1.7^{\mathrm{a}}$ & $1.6^{\mathrm{b}}$ & $1.7^{\mathrm{a}^{* *}}$ & \multirow{2}{*}{0.03} \\
\hline & 24 hours & 1.7 & 1.6 & $1.6^{*}$ & \\
\hline
\end{tabular}

It is not clear why $\mathrm{m}$. longissimus from $\mathrm{Sm}_{24}$ contained more glycogen and showed less glycogenolysis up to one hour post mortem. Nor is it clear why the creatine phosphate depletion rate was higher, average sarcomere lengths were shorter, and WBSF was higher for $\mathrm{Sm}_{24}$. One explanation could be the deactivation of mitochondrial functions as found in hibernating or fasting animals where $\mathrm{Ca}^{2+}$ concentration increases in the mitochondria, which deactivates mitochondrial ATPase with subsequent decrease in ATP production and ATP hydrolysis (Bronnikov et al., 1990). In the post-mortem period, dual elevated sarcoplasmic $\mathrm{Ca}^{2+}$ concentration is proposed, namely that elevated $\mathrm{Ca}^{2+}$ in sarcoplasm from sarcoplasmic reticulum (Savell et al., 2005) and from $\mathrm{Ca}^{2+}$ that was stored in the mitochondria leaks into the sarcoplasm. Buege \& Marsh (1975) described the involvement of mitochondrial ATPase with cold shortening.. Sarcoplasmic Ca ${ }^{2+}$ triggers muscle contraction (Hopkins, 2006) and therefore creatine phosphate depletion, sarcomere shortening and tough meat. 
Table 5 Effect of breed type and feed withdrawal period on Warner-Bratzler shear force at 1,7 and 14 days post mortem

\begin{tabular}{|c|c|c|c|c|c|}
\hline \multirow{2}{*}{ Warner-Bratzler shear force $(\mathrm{kg} / 12.5 \mathrm{~mm} \theta)$} & \multirow{2}{*}{ Feed withdrawal } & \multicolumn{3}{|c|}{ Breed } & \multirow{2}{*}{ SEM } \\
\hline & & Brahman & Nguni & Simmental & \\
\hline \multirow[t]{2}{*}{1 day } & 3 hours & 8.1 & 8.2 & $8.7^{*}$ & \multirow{2}{*}{0.45} \\
\hline & 24 hours & $8.5^{\mathrm{a}}$ & $9.0^{\mathrm{a}}$ & $10.4^{\mathrm{b}^{\star \star}}$ & \\
\hline \multirow[t]{2}{*}{7 days } & 3 hours & 5.9 & 5.8 & $6.1^{\star}$ & \multirow{2}{*}{0.4} \\
\hline & 24 hours & $5.9^{\mathrm{a}}$ & $5.9^{\mathrm{a}}$ & $6.9^{b^{* *}}$ & \\
\hline \multirow{2}{*}{14 days } & 3 hours & 4.9 & 4.9 & $5.3^{*}$ & \multirow{2}{*}{0.32} \\
\hline & 24 hours & $4.7^{\mathrm{a}}$ & $5.5^{\mathrm{b}}$ & $6.7^{\mathrm{c}^{\star \star}}$ & \\
\hline
\end{tabular}

${ }^{\mathrm{a}, \mathrm{b}}$ Means with different superscripts within the same row differ significantly $(P<0.05)$

${ }^{*},{ }^{* *}$ Means with different superscripts within the same column differ significantly $(P<0.05)$

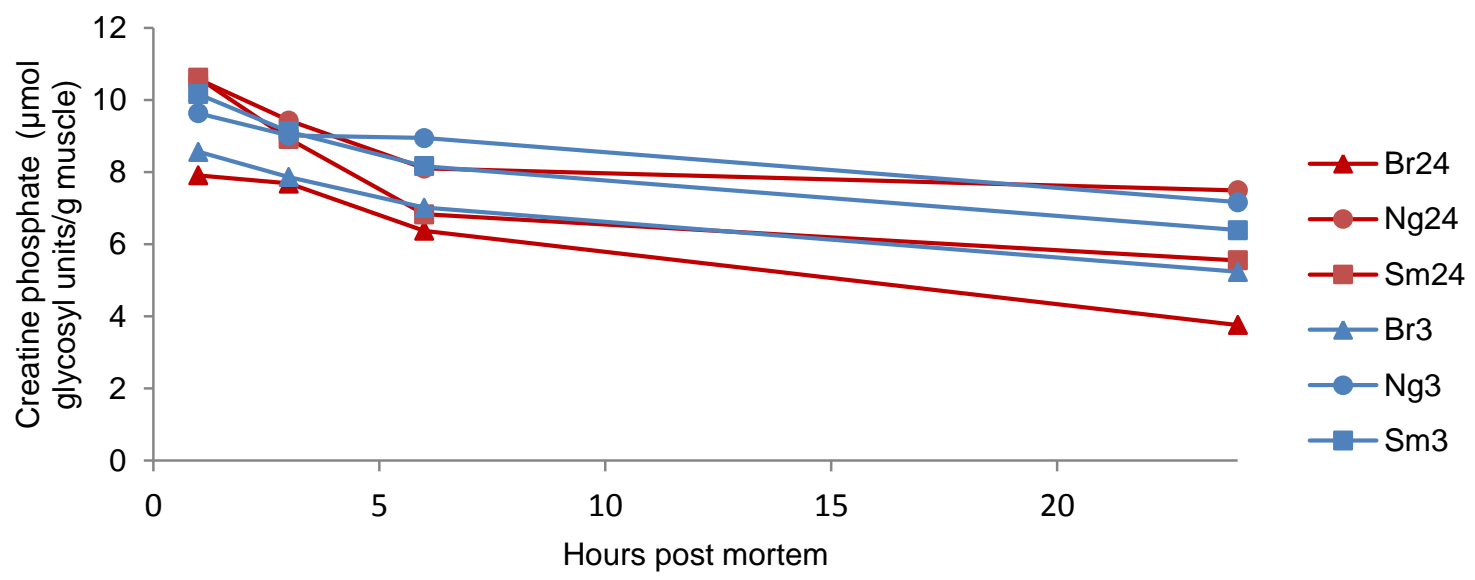

Figure 3 Creatine phosphate profile of $m$. longissimus of Brahman-, Nguni- and Simmental-type cattle subjected to three or 24 hour' feed withdrawal

The average sarcomere lengths were longer $(P<0.05)$ for $\mathrm{Br}_{24}$ compared with $\mathrm{Ng}_{24}$ and $\mathrm{Sm}_{24}$ at one day post mortem. The average sarcomere lengths were shorter $(P<0.05)$ for $\mathrm{Ng}$ than for $\mathrm{Br}$ and $\mathrm{Sm}$ at one and three days post mortem. This could have been due to breed differences because none of the groups fell in the cold shortening window. For breed type in combination with feed withdrawal, there were no significant differences in WBSF between breeds subjected to three hours feed withdrawal at any of the post-mortem time intervals. This emphasises the importance of sufficient available energy in muscle in meat tenderness, and shows that some breeds are affected more negatively than others by longer feed withdrawal.

\section{Conclusion}

When feed was available up to three hours before slaughter, irrespective of breed type, meat tenderness was not affected negatively. Extended feed withdrawal in Sm delayed glycogenolysis up to one hour post mortem, and additional sarcomere shortening occurred to such a degree that meat from Sm was the toughest. It is clear that feed withdrawal of 24 hours has a significantly negative effect on WBSF of Sm. Feed must be provided to Sm up to three hours before slaughter to prevent excessive sarcomere shortening and meat toughness. When feed withdrawal for longer periods (24 hours) is inevitable, and animals are transported over long distances or kept in holding pens for extended periods without food, carcasses must be stimulated electrically to drive complete glycolysis at a faster rate early post mortem.

\section{Acknowledgements}

The support and financial aid of the Red Meat Research and Development Trust are much appreciated. 


\section{Authors' Contributions}

Conception and design LF, PES; data collection, analyses and drafting of paper AON; and critical review ECW

\section{Conflict of Interest Declaration}

There are no conflicts of interest.

\section{References}

Abouzeed, Y.M., Hariharan, H., Poppe, C. \& Kibenge, F.S.B., 2000. Characterization of Salmonella isolates from beef cattle, broiler chickens and human sources on Prince Edward Island. Comp. Immunol. Microb. 23, 253-266.

AMSA., 1995. Research guidelines for cookery, sensory evaluation and instrumental tenderness measurements of fresh meat. American Meat Science Association in cooperation with National Live Stock and Meat Board, Chicago, Illinois

Bardale, R., 2011. Principles of forensic medicine and toxicology. JP Medical Ltd, New Dehli, pp 141-144.

Bate-Smith, E.C., 1949. Organoleptic tests in the food industry. I. General introduction and quality of animal products. J. Soc. Chem. Ind. 68, 78-80.

Bendall, J.R., 1951. The shortening of rabbit muscles during rigor mortis; its relation to the breakdown of adenosine triphosphate and creatine phosphate and to muscular contraction. J. Phys. 114, 71-88.

Bendall, J.R., 1973. Post mortem changes in muscle. In G.H. Bourne (eds). The structure and function of muscle. Volume II, Structure, Part 2 (pp. 243-309). Academic Press, New York

Bertram, H.C., Stødkilde-Jørgensen, H., Karlsson, A.H. \& Andersen, H.J., 2002. Post mortem energy metabolism and meat quality of porcine $m$. longissimus as influenced by stunning method -A 31P NMR spectroscopic study. Meat. Sci. 62, 113-119.

Bester, J., Matjuda, L.E., Rust, J.M. \& Fourie, H.J., 2005. The Nguni: A case study. Community-Based Management of Animal Genetic Resources. Proceedings of the workshop in Mbabane, Swaziland, 7-11 May 2001.

Bronnikov, G.E., Vinogradova, S.O., \& Chernyak, B.V., 1990. Regulation of ATP hydrolysis in liver mitochondria from ground squirrel. FEBS Letters, 266(1-2), 83-86.

Buege, D.R. \& Marsh, B.B., 1975. Mitochondrial calcium and post mortem muscle shortening. Biochem. Biophys. Res. Co. $65,478-482$

Campbell, M.K., 1995. Biochemistry. Second edition. Saunders College Pub, Wiley, New York.

Dalrymple, R.H. \& Hamm, R., 1973. A method for the extraction of glycogen and metabolites from a single muscle sample. Int. J. Food. Sci. Tech. 8, 439-444.

Ferguson, D.M. \& Warner, R.D., 2008. Have we underestimated the impact of pre-slaughter stress on meat quality in ruminants? Meat Sci. 80, 12-19.

Frisch, J.E., 1973. Comparative drought resistance of Bos indicus and Bos taurus crossbred herds in Central Queensland 2. Relative mortality rates, calf birth weights, and weights and weight changes of breeding cows. Aust. J. Exp. Agr. 13, 117-126.

Fujita, S., Okamoto, R., Taniguchi, M., Ban-Tokuda, T., Konishi, K., Goto, I., Yamamoto, Y., Sugimoto, K., Takamatsu, N., Nakamura, M., Shiraki, K., Buechler, C. \& Ito, M., 2013. Identification of bovine hibernation-specific protein complex and evidence of its regulation in fasting and aging. J. Biochem. 153, 453-461.

Hamm, R., 1974. Water-holding capacity of meat. In D.J.A. Cole \& R.A. Lawrie (eds.). Meat (pp. 321-338). Butterworth \& Co., London, UK.

Hammond, A.C., Chase, Jr. C.C., Bowers E.J., Olson, T.A. \& Randel, R.D., 1998. Heat tolerance in Tuli-, Senepol-, and Brahman-sired F1 Angus heifers in Florida. J. Anim. Sci. 76, 1568-1577.

Hannula, T. \& Puolanne, E., 2004. The effect of cooling rate on beef tenderness: The significance of $\mathrm{pH}$ at $7^{\circ} \mathrm{C}$. Meat Sci. 67, 403-408.

Hegarty, P.V.J. \& Naude, R.T., 1970. The accuracy of measurement of individual skeletal muscle fibers separated by a rapid technique. Laboratory Practice 19, 161-163.

Hopkins, M., 2006. Skeletal muscle physiology. Continuing education in anaesthesia. Anaesth. Crit. Care. Pa. 6, 1-6.

Howard, A. \& Lawrie, R. A., 1956. Special report of Food Investigators Bd. (No. 63), London, England.

Immonen, K. \& Puolanne, E., 2000. Variation of residual glycogen-glucose concentration at ultimate pH values below 5.75. Meat. Sci. 55, 279-283.

Jama, N., Muchenje, V., Chimonyo, M., Strydom, P.E., Dzama, K. \& Raats, J.G., 2008. Cooking loss components of beef from Nguni, Bonsmara and Angus steers. Afr. J. Agr. Res. 3, 416-420

Jeacocke, R.E., 1984. The kinetics of rigor onset in beef muscle fibers. Meat. Sci. 11, 237-251.

Judge, M.D., Aberle, E.D., Forrest, J.C., Hedrick, H.B. \& Merkel, R.A., 1989. In: Principles of meat science (2nd ed.) (pp. 46, 351). Kendall/Hunt, Dubuque.

Keppler, K. \& Decker, D., 1974. In: H.-U. Bergmeyer (ed.). Methods of enzymatic analysis. pp. 1127-1131, Academic Press, New York and London.

Lamprecht, W. \& Stein, P., 1965. Creatine phosphate. In: H.-U. Bergmeyer. Methods of enzymatic analysis nkm (ed.), pp 610-616, Academic Press, New York and London.

Lawrie, R.A. 1953. The onset of rigor mortis in various muscles of the draught horse. J, Phys. 121, 275-288.

Lepen, J.M., 1996. Breed characterization studies in Namibia. Agricola Specifications, 21.

Mader, T.L., Holt, S.M., Hahn, G.L., Davis, M.S. \& Spiers, D.E., 2002. Feeding strategies for managing heat load in feedlot cattle. J. Anim, Sci. 80, 2373-2382.

Malatesta, M, Biggiogera, M. \& Zancanaro, C., 2007. Hypometabolic induced state: A potential tool in biomedicine and space exploration. Rev. Environ. Sci. Bio. 6 (1-3) pp. 4. 
Marks, v., 2005. Glucose: Metabolism and maintenance of blood glucose level. Encyclopedia of Human Nutrition. 2nd ed. pp 398-404.

Newsholme, E.A. \& Leech, A.R., 1983. Biochemistry for the Medical Sciences. Wiley, Chichester

Newsholme, E.A. \& Start, C., 1979. Regulation in metabolism. Wiley, Chichester.

O'Neill, H.A., 2016. The influence of catecholamines on energy metabolism and selected meat quality attributes of three commercial beef breeds. Doctoral dissertation. University of Pretoria, Pretoria.

Pearson, A.M. \& Young, R.B., 1989. Post mortem changes during conversion of muscle to meat. In: Muscle and meat biochemistry. Academic Press, San Diego, CA

Pösö, A.R. \& Puolanne, E., 2005. Carbohydrate metabolism in meat animals. Meat. Sci. 70, 423-434.

Purwanto, B.P., Abo, Y., Sakamoto, R., Furumoto, F. \& Yamamoto, S., 1990. Diurnal patterns of heat production and heart rate under thermoneutral conditions in Holstein Friesian cows differing in milk production. J. Agr. Sci. 114, 139-142.

SAS. 2008. SAS Users guide: Statistics. SAS Inst. Inc., Cary, NC.

Savell, J.W., Mueller, S.L. \& Baird, B.E., 2005. Review: The chilling of carcasses. Meat. Sci. 70, 449-459.

Schaefer, A.L., Dubeski, P.L., Aalhus, J.L. \& Tong, A.K.W., 2001. Role of nutrition in reducing ante mortem stress and meat quality aberrations. J. Anim. Sci. 79, E91-E101.

Scheffler, T.L., Park, S. \& Gerrard, D.E., 2011. Review: Lessons to learn about post mortem metabolism using the AMPKy3R200Q. Meat. Sci. 89, 244-250.

Staples, J.F., 2016. Metabolic flexibility: Hibernation, torpor, and estivation. Comp. Phys, Mar 15.

Strydom, P.E., Frylinck, L., van der Westhuizen, J. \& Burrow, H.M., 2008. Growth performance, feed efficiency and carcass and meat quality of tropically adapted breed types from different farming systems in South Africa. Aust. J. Exp. Agr. 48, 599-607.

Tarrant, P.J., McLoughlin, J.V. \& Harrington, M.G., 1972. Anaerobic glycolysis in biopsy and post mortem porcine longissimus muscle. Proceedings of the Royal Irish Academy. Section B: Biological, Geological, and Chemical Science, 72, 55-73.

Tornberg, E., 1996. Biophysical aspects of meat tenderness. Meat Science, 43, S175-S191.

Vetharaniam, I., Thomson, R.A., Devine, C.E. \& Daly, C.C., 2010. Modelling muscle energy-metabolism in anaerobic muscle. Meat Sci. 85, 134-148.

Voisinet, B.D., Grandin, T., O'Connor, S.F., Tatum, J.D. \& Deesing, M.J., 1997 Bos indicus-cross feedlot cattle with excitable temperaments have tougher meat and a higher incidence of borderline dark cutters. Meat Sci. 46, 36737. 